\title{
The Creation of New Social Infrastructure System to Spread the Next-generation Vehicles - An example of Yakushima Island's "Zero Emissions" Initiative
}

\author{
Hidetaka Ichikawa \\ Faculty of Law, Economics and Humanities, Kagoshima University, Japan
}

Copyright (C) 2015 by authors, all rights reserved. Authors agree that this article remains permanently open access under the terms of the Creative Commons Attribution License 4.0 International License

\begin{abstract}
CO}_{2}$ reduction has become a global initiative. Hybrid and electric vehicles (EVs) will not only reduce the use of gasoline, but also significantly contribute to the reduction of $\mathrm{CO}_{2}$. Next-generation vehicles that run on electricity and fuel cells that continue reducing the environmental load are required for the future. However, the spread of these next-generation vehicles has failed to proceed easily. Hybrid vehicles utilize both gasoline and electricity as a power source, electric vehicles run on battery power and fuel cell vehicles (FCVs) use hydrogen. Charging facilities are required to utilize electric vehicles and fuel cell vehicles. Compared to gasoline vehicles, there are four factors that hinder the spread of next-generation vehicles, 1 . High selling price, 2. Lack of charging facilities, 3. Long charging time, 4. Shortage of cruising distance. FCVs include 1. and 2. In order to reduce the high selling price, there is no choice but to rely on product innovation by automobile manufacturers. For the lack of charging facilities, it will be a problem that cannot be solved by only the automotive manufacturers, the cooperation of national and local governments is required. Without the overall improvement of infrastructure, the stagnation of next-generation vehicles ales will continue. To reverse this trend, new social infrastructure systems and lifestyles changes are needed to stimulate the purchasing willingness of consumers. In this paper, we discuss the dissemination activities Kagoshima Prefecture has been conducted in Yakushima. This research thus proposes the creation of new social infrastructure system as well as a new lifestyle changes using Yakushima Island as an example which we believe can increase the spread of next-generation vehicles.
\end{abstract}

Keywords Infrastructure System, Next-generation Vehicles, Zero Emissions, Hydrogen Society

\section{Yakushima Island as "Zero Carbon Emission Island" Initiative}

Yakushima Island, a World Natural Heritage Site located in Kagoshima Prefecture, Japan, is almost completely powered by hydroelectricity. Focusing on this unique island, Kagoshima Prefecture is promoting the "Zero Carbon Emission Island" initiative, which aims to create a developed area where carbon dioxide $\left(\mathrm{CO}_{2}\right)$ emission is effectively reduced.

The electricity business in Kagoshima has a long history. Power in Kagoshima was mostly generated through hydropower, utilizing the surrounding mountainous terrain. This is why Satsuma (a powerful feudal domain in Tokugawa, Japan) originally strove to introduce Western technology to the area. Kyushu Electric Power Co., Inc. Kagoshima Branch (1998) explains that during the era of Shimadzu Tadayoshi, the 29th feudal lord of Satsuma, there was a hydroelectric power station that used a $35 \mathrm{~m}$ high waterfall at the Iso Garden, which was at Shimadzu's villa. During that time on a global scale, Kagoshima seemed to be behind; however, locally it was at this time that the electric light was only just installed in Tokyo and Yokohama, said to be a radical development.

Above all, in Kagoshima Prefecture, it is expected that renewable energy will see widespread usage, thus becoming a viable alternative to nuclear power.

Yakushima Island is the fifth largest island in Japan with a perimeter of $132 \mathrm{~km}$ and an area of $503 \mathrm{~m} 2$. In the book "Floating Clouds," Fumiko Hayashi writes that "in Yakushima it rains 35 days in one month." The area's high rainfall owes to its mountainous conditions. Yakushima Island is blessed with pristine natural environment and abundant water, which the inhabitants use for hydroelectric power to generate much of the islands power. 
According to "The History of the Power in Kagoshima," the introduction of hydropower was planned early owing to the area's inconvenient outlying geographical location and its abundant rainfall. In 1916, Kagoshima electricity obtained the water rights to Anbo River and tried to build a fertilizer plant, although this was not successful. In 1924, the Yakushima Hydroelectricity Company was established. Yakushima Denko is responsible for the power supply in Yakushima and as mentioned above, the island's power demand has been met by hydroelectric power. Yakushima will thus serve as a model for Japan who aims to increase the percentage of renewable energy. We therefore have to think of how to effectively use the available capacity of hydroelectric power and also how to promote its benefits in order to overcome the disadvantages of the island.

\section{Use of Next-generation Vehicles}

While power on Yakushima is generated through renewable hydropower, this leads to the downside that gasoline costs about $20 \%$ more than it does on the mainland. This has led to a move towards electric vehicles. The use of these electric vehicles by many people means a saving in costs of about $50 \%$. If gasoline powered vehicles can be replaced by electric vehicles, the economic burden of the people in Yakushima can be reduced and the ideal of zero emissions and $\mathrm{CO}_{2}$-free zone can be realized.

Due to the islands small size, most people in Yakushima can complete their daily activities 30 minutes or less, traveling within an average range of about $20 \mathrm{~km}$. One disadvantage of electric vehicles is the time it takes for a single charge. In essence, electric vehicles are economical and a reasonable alternative in Yakushima(Ichikawa and Shiraki 2012).

Up till this point, the design, mileage, low price etc. of internal combustion engine cars by manufactures has been done to meet the wants of the consumer. However will the new electric cars, FCV and PHV(plug-in hybrid car) be as accepted by the public and enter into the mainstream? As long as the problems with these cars, such as short cruise distance, the possibility of losing power, are not solved the answer is most likely no. Along with these problems, the lack of charging infrastructure must be addressed. Next-gen vehicles will not become mainstream unless the cost to run them is equal to that of a conventional gas one.

There is also an issue in the manufacturing of next-gen vehicles. The process and parts are different from the conventional cars. However presently both manufacturing companies and supple companies are coming together to figure out produce standardized parts for a universal computer system to assemble wherever the factory may be(Clark and Fujimoto1990, Fujimoto2000, Fujimoto2001a, Fujimoto 2001b, Nobeoka2006).

Electric cars have also begun to be manufactured by new companies outside of traditional car manufactures, for example Tesla in the United States. Tesla makes only electric cars and their Model S, released in 2012, has sold about 60000 worldwide (Nikkei Monozukuri2015). The Model S with its high selling price of 10 million yen, is seemingly aimed at those people who are well off finically and high environmental-oriented. However it is still inferior to gas cars in cruising range. To address this, their new compact sedan the 'Model 3' will be released in 2017. This car will have a much improved battery life with the ability to travel around $400 \mathrm{~km}$ on only a single charge(Nikkei Monozukuri2015).

This show that the production of electric cars can be done by new company's independent from the big auto makers. This is because electric cars are much easier to make, with just the battery and engine being the main part. Gasoline cars constitute of parts numbering from 20 - 30 thousand, however electric cars are only $10 \%$ of that with $2-3$ thousand parts. And now the big auto makers are also trying to capitalize of this easer production method by moving to a module process type rather than the standard combinational of many parts.

\section{Use of Renewable Energy}

Accidents such as those at the Fukushima nuclear power plant are not the only dangers posed by nuclear power. In this paper, we thus consider more secure, safer, and cleaner alternatives to nuclear power. We suggest renewable energies including, amongst others, solar power, solar thermal power, geothermal energy, water power, wind power, and biomass energy. Renewable energies are based on natural energy, so they do not emit the large amounts of $\mathrm{CO}_{2}$ like that of thermal power generation. Nuclear power also has a huge problem when it comes to waste management/containment. On the other hand, there is no such problem in the use of renewable energy. Renewable energies have been used worldwide, with their use varying from country to country depending on the terrain. For example, wind power and solar power methods are being developed in Spain and the United States. In Japan, hydropower is the most popular, but wind power is not widely accessible because of the country's terrain and the difficulty of setting up it. On the other hand, Japan is surrounded by the sea: it could therefore make use of offshore wind.

According to an investigation by the International Energy Agency (IEA), the amount of electricity generated by renewable energy sources in 2008 accounted for only $18 \%$ of electricity generated in the world. Iida (2012) states that the diffusion of renewable energy power generation in Japan is approximately $10 \%$. This percentage has not changed in the last 10 years. However, there has been an increase of $18 \%$ in renewable energy power generation in Germany over the same period, and an increase of $20 \%$ in Spain. While Germany and Spain are already advanced in the use of renewable energy, Japan has the potential to develop in this area even more. In explaining the reasons for the delay in 
promoting renewable energy in Japan, Iida (2012) identifies four problems: (1) lack of a support systems, (2) monopolization of the transmission line by power companies, (3) excess of the local government and the country regulations, and (4) absence of any agreements with the local community.

Regarding the first problem, feed-in tariffs for renewable energy were adopted late in Japan. In Spain and Germany, where it has already been adopted, solar cell manufacturers, such as Q-Cells, have increased their market share. In the early part of this century, Japanese companies, such as Kyocera and Sharp, owned the majority of the solar power share. These were reversed in Western companies because they effectively used the feed-in tariff. There is now momentum in Chinese companies such as Suntech Power and JA Solar, both offering low costs that will dominate the market.

For the second problem, the power industry tends to promote nuclear power rather than renewable energy because each power company has a monopoly on the wall next to the power transmission network.

The third problem reflects the adverse effects of the Japanese legacy system. Companies trying to take advantage of renewable energy are hampered by numerous regulations. For example, geothermal energy has been placed under the control of the National Parks, meaning that no other party is able to actively use this energy. To attempt to use this, one has to submit numerous applications to more than one municipality, prefecture, city, government, and so forth.

The fourth problem is related to water rights, which is a major concern in the region. In setting up hydropower, one must get water rights permission from those downstream. This is a difficult task. To make this easier, it will be necessary to create awareness of renewable energy. The biggest advantages of renewable energy are that it is eco-friendly and clean. It is, however, difficult to understand. The biggest concern in terms of water rights is that these rights might be infringed upon.

Renewable energy, however, fails to solve many problems in Japan, with the biggest issue in terms of this energy is the lack of understanding. The merit of using renewable energy is that it is a clean energy and that we are able to reuse many times. By acknowledging the benefits, we can view renewable energy as a semi-permanent energy source.

\section{Dependency on Large-scale Power Generation}

Carr (2008) states that in the late 19th century, each household self-generated enough power to correspond to the demand, however nowadays, consumers rely on large-scale power generation facilities. As per the economies of scale, when the electricity price is reduced, we see the development of many appliances. An electricity-dependent lifestyle has evolved to maximize the benefits of low cost power. This means that you can use the required amount of electricity to enrich your life without worrying about a lack of power. As long as economic development continues, the amount of power you need will be increasingly available. Thus, economies of scale in power will advance, promoting the construction of larger power plants that can generate electricity efficiently, such as those generating nuclear power.

Currently, this flow is reversed: we need not depend on a power company rather, each household can produce the power required, even if only in small amounts. Renewable energy enables the realization of this ideal.

\section{New Lifestyle}

With the spread of electric vehicles, a new lifestyle is proposed in Yakushima. An electric car brings not only zero emission but it is also $\mathrm{CO}_{2}$-free, low cost, and convenient. However, in Yakushima, electric cars have not yet sufficiently diffused into society and they have failed to fully spread throughout the island.

We have now discussed the environment surrounding electric vehicles. However, what elements are missing? And what should be improved? If these problems are eliminated, will electric vehicles be prevalent in Yakushima? Will we achieve zero emissions and be $\mathrm{CO}_{2}$-free? We now summarize the problems to be solved, as well as the potential for electric vehicles.

Problems include the following:

1. High selling price of electric vehicles compared to equivalent gasoline vehicles.

2. Lack of infrastructure on the island, namely the lack of charging facilities.

3. Lack of understanding about the electric car.

4. Impact on existing industries, and the creation of new industries.

In terms of the first point, not only national and local government subsidies are needed, but also the innovation to reduce the selling price of electric vehicles by automobile companies is necessary. It is important to be able to sell to consumers without indebting them.

With regard to the second point, not only subsidies for charging facilities and equipment are needed but also the development of a small, lightweight, replaceable battery, such as a $100 \mathrm{~V}$ household power supply unit. We could additionally expect increased cruising range with the improved battery technology.

Third, on Yakushima Island, 28.7\% of the population is above 65 years. For them, a car, and driving, is a necessity of life. Many elderly people drive often. For this reason, a simple way of charging batteries during operation to avoid anxiety will be necessary. Highlighting the benefits of electric vehicles alone is not enough to ensure any purchases, we also need to create awareness of electric vehicles among the islanders. As described in this paper, the automotive operating environment in Yakushima is limited, therefore the possibility of running out of battery charge is similar to a 
gasoline shortage when driving a vehicle with an internal combustion engine. As long as the battery is still functioning properly, we must ensure that an "out of battery" situation never occurs during the daytime use of the electric vehicle by charging the battery each night.

Fourth, the spread of electric vehicles may have a major impact on conventional industries and business. For example, gas stations would no longer be needed. Conventional garages will have to be tailored to electric vehicles, as mechanic technology may be different for electrical systems.

Resuming operations at nuclear power plants is difficult, although it may be required owing to increased power rates and rolling blackouts. Therefore, the potential of hydropower in Yakushima will become coveted by many organizations. The disadvantage of being a solitary island hampers the development of new industries, for example, young people have left for the city to find employment. With the abundant hydropower situation, we should actively try to attract new companies. When weighing up the disadvantage of being away from the city with the advantage of a stable power supply, there is potential for companies to advance in Yakushima. Hydroelectric power provided by the abundant water supply in Yakushima is a renewable energy source that does not harm nature and that will bring about a new lifestyle.

\section{The Creation of New Social Infrastructure System}

The shift to a hydrogen fuel based society takes time. Thinking not just on a manufacturing level, this shift would be beneficially for Japan and also the World. We must consider the environmental problems we all face as well as the fact that existing power generation fuel such as coal and oil will one day run out. No matter how hard it is or how much time it takes we must make a change towards a zero emission society. The Ministry of Economy, Trade and Industry released a road map plan in June 2015 laying out the future of renewable energy in Japan. In this plan they state that by 2030 they wish to raise the market scale of renewable energy to 1 trillion yen and then to 8 trillion by 2050 .

The aim of a hydrogen fuel based society is 1. Energy conservation 2. Energy security 3 . Environmental protection 4. Industrial and Regional development.

There are 3 steps in getting to this society.

- Global market acquisition of hydrogen fuel cells leading to the wide spread of fuel cell-powered cars.

- Establishment of large scale natural energy production facilities, such as hydrogen plants.

- In order to realize a truly $\mathrm{CO} 2$ free society, implement a system that uses only renewable energy, maximizing the production, storage and usage of new energies like hydrogen.

If we follow these steps over the next $30-50$ years it is possible to achieve this new society.

Japan is a country with very little natural resources and is reliant on importation, meaning that it is greatly effect by what goes on in countries. However if we can realize this plan of a hydrogen fuel based society this will all change and Japan will be in complete control of its energy needs. The transmission will not be easy and will require the cooperation between the big 3, the country, industry and the universities. Sasaki(2015) explains that as a transition to the hydrogen society, we are expected to \{carbon cycle society (internal combustion engine + fossil fuel) $\} \Rightarrow$ hydrogen utilization society (fuel cell + fossil fuel) $\} \Rightarrow$ pure hydrogen society (fuel cell $+\mathrm{CO}_{2}$-free hydrogen). Hydrogen is a natural renewable resource and so is available anywhere. Utalizing this and moving towards a pure hydrogen fuel based society will solve many problems in Japan a lead to a much better world for our children.

\section{Conclusions}

With a focus on renewable energy, we have, in this paper, proposed the creation of a new lifestyle through taking advantage of electric vehicles. In Japan, most nuclear power plants are currently inactive, with reliance now mostly on alternative methods like thermal power. However, thermal power generation has environmental impacts, such as $\mathrm{CO}_{2}$ emissions. As has become evident in the accident at Fukushima plant, nuclear power also poses a high risk for the environment. The only way to remove the environmental risk is by using renewable energy. Power generation from one facility is very small. In Japan, mountainous areas account for approximately $65 \%$ of the landscape; therefore, since hydropower has been used since ancient times, huge potential exists for renewable energy.

Hydroelectric power does not result in water pollution, meaning that we can repeatedly use the water. Although there are problems, such as those with water rights, while rediscovering the feasibility of hydropower, I wondered if it presents an opportunity to review hydropower as an alternative to conventional power generation.

I used Yakushima as an example owing to its specific situation, abundant annual rainfall, and use of hydroelectric power. It is possible to use hydroelectric power effectively for electric vehicles. Also, because it is registered as a World Natural Heritage Site, Yakushima appeals to nature conservationists. Most of the island is covered by forest, and if we can achieve $\mathrm{CO}_{2}$-free and zero emissions, we can enhance the value of its presence. If the alternative to gasoline-powered vehicles is electric vehicles that not emit $\mathrm{CO}_{2}$, the natural environment can, as a result, be protected. The price of gasoline in Yakushima is about 20\% higher than in mainland Japan. It would, therefore, be a great benefit to change from gasoline to electrical energy for powering vehicles. The use of renewable energy is a competitive advantage in other areas as well. In Yakushima, very small amounts of hydroelectric power have begun to be implemented. As there are many rivers and waterfalls, it is expected that there are many places from which to take advantage of hydroelectric power. Should we take advantage 
of these places, we will be able to interchange power units for residents. This will serve as a model of power generation and a supply system based on a recycling orientation that not only Japan but also the world should aim toward.

It is expected that renewable energy will be used in many places in the future as energy recycling systems become more efficiently constructed. Yakushima can be considered a cutting-edge model for this change. We must ensure the creation of new social infrastructure system to spread the next-generation vehicles that does not burden the future.

\section{REFERENCES}

[1] Carr, G. Nicholas. (2008) "The Big Switch: Rewiring the World, From Edison to Google", W W Norton \& Co Inc

[2] Chesbrough Henry(2007)"Open Business Models : How to Thrive in the New Innovation Landscape", Harvard Business School Press

[3] Clark B.Kim and Fujimoto Takahiro(1990)"The Power of Product Integrity", Harvard Business Review, November-December

[4] Fujimoto Takahiro (2000)"20th Century Japanese-style production system", Hitotsubashi Business Review, 2000,WIN(in Japanese)
[5] Fujimoto Takahiro(2001a)"'Introduction to Production Management I ",Nikkei Inc. (in Japanese)

[6] Fujimoto Takahiro(2001b)"Introduction to Production Management II", Nikkei Inc. (in Japanese)

[7] Hayashi Fumiko(1951) "Floating Clouds", (in Japanese)

[8] Ichikawa Hidetaka and Shiraki Nobuhiko(2012)"The diffusion electric vehicles in Yakushima : Electric Car will make a new lifestyle", Journal of Economics and Sociology, Kagoshima University, March 2012, pp.101-116

[9] Iida Tetsuya(2012)"The ability of renewable energy the more penetrate the more price decline", Nikkei Inc., April $15^{\text {th }} 2015$, (in Japanese)

[10] International Energy Agency(http://www.iea.org/)

[11] Kyushu Electric Power Co., Inc. Kagoshima Branch.(1998)" The History of the Power in Kagoshima" (in Japanese)

[12] Ministry of Economy, Trade and Industry (2015)"Road map to hydrogen fuel based society and fuel cell", June $23^{\text {rd }}$ 2015(in Japanese)

[13] Nikkei Monozukuri(2015)" Mainstream of the world EV", May 2015, pp.42-71 (in Japanese)

[14] Nobeoka Kentaro(2006) "Introduction to Management of Technology", Nikkei Inc. (in Japanese)

[15] Sasaki Kazunari(2015)"Economics Classroom Prospects and Challenges to the hydrogen society (1)", Nikkei Inc. April $20^{\text {th }} 2015$ (in Japanese) 